\title{
PERCEPTION OF CLIMATE CHANGE - A SURVEY AMONG AGRICULTURAL ADVISORS
}

Đurđica Žutinić1, Magdalena Zrakić Sušac ${ }^{2}$

*Corresponding author E-mail: mzrakic@agr.hr

\begin{abstract}
A R T I C LE IN F O
A B S T R A C T

Original Article

Received: 08 December 2020

Accepted: 24 May 2021

doi:10.5937/ekoPolj2102307Z

UDC 338.262:551.583

This paper is based on the results of an empirical study conducted on a sample of 103 employees of the Croatian Agricultural and Forestry Advisory Service in mid2018. The main goal of the study was to determine the opinions and attitudes of agricultural advisors on climate change. Attitudes were measured using 16 statements which summarize three composite indicators (awareness

Keywords:

knowledge, climate change, perception, agricultural advisors of anthropogenic causes and consequences, mitigation responsibility, and indifference and defeatism towards climate change). Results of the research show that the respondents are relatively aware of the anthropogenic impact on climate change, as well as wider consequences JEL: Q16, Q53, Q54 of climate change on society and the environment (MKIs $=3.83$ ). On average, respondents expressed strongest agreement with statements about political and civic responsibility in climate change mitigation $(\mathrm{MKIo}=4.06)$. Most agricultural advisors perceive climate change as dangerous for the stability of domestic farming, and as many as $92.4 \%$ of respondents believe that farmers do not have the necessary knowledge to successfully deal with the risks of climate change in their own production.
\end{abstract}

(C) 2021 EA. All rights reserved.

\section{Introduction}

In the last few decades, climate change has been a frequent subject of political, scientific and public debate, both in the world and in Croatia. Research shows that opinions and attitudes of experts, scientists and the public about the causes of climate change, as well as the consequences through which they manifest themselves, are not

1 Đurđica Žutinić, Ph.D., Full Professor, University of Zagreb, Faculty of Agriculture, Department of Agricultural Economics and Rural Development, Svetošimunska cesta 25, 10000 Zagreb, Croatia, Phone: +385 12393 742, E-mail: dzutinic@agr.hr, ORCID ID (https://orcid.org/0000-0002-0577-1109)

2 Magdalena Zrakić Sušac, Ph.D., Assistant Professor, University of Zagreb, Faculty of Agriculture, Department of Agricultural Economics and Rural Development, Svetošimunska cesta 25, 10000 Zagreb, Croatia, Phone: +385 123940 60, E-mail: mzrakic@agr.hr, ORCID ID (https://orcid.org/0000-0002-0577-1109) 
mutually aligned, but are instead shaped by socio-cultural characteristics, vulnerability of individual communities and geographical affiliation (Howel et al., 2015). Climate change is primarily a natural phenomenon; however, it is also increasingly influenced by social activities and the way of life of modern societies.

This has stirred a global political debate and stimulated the adoption of numerous strategic documents and guidelines aimed at reducing society's negative impact on the environment and fostering adaptation to climate change. At the global level in recent times, the international organization United Nations (UN) promoted the maintenance of the average increase in global temperature at $1.5-2^{\circ} \mathrm{C}$ with the Paris Agreement (2016), through joint action of all signatory states. Today, this agreement is complemented and directly linked to the "Goals of the 2030 Agenda for Sustainable Development," which balances the environmental, societal and economic dimensions. Among the 17 goals of sustainable development, goal number 13 ("Climate action") is directly aimed at taking urgent action to combat climate change and its consequences.

Of all the economic sectors, the agricultural sector is particularly vulnerable to climate change, as all direct climate characteristics (temperature, precipitation and weather conditions) significantly influence production. It is inevitable that climatic conditions are changing and that farming must adapt to emerging natural trends or new risks in the production process. Climate-smart agriculture is increasingly promoted as one of the solutions to the problems of food safety and environmental degradation, as well as a way of adaptation to climate change (Thierfelder and Wall, 2009; Derpsch et al., 2008).

In the last few decades, even Croatian agriculture has been increasingly exposed to extreme weather phenomena such as floods, hail, water shortages due to droughts, fires, etc., which significantly lower yields and affect the volume of production and crop quality. According to the data of the Government of Croatia, in 2018 losses of almost HRK 195 million ( $\approx \$ 33$ million) due to direct damage were recorded in agriculture, that is, on land and in livestock. Furthermore, it is predicted that by 2050, the yield of agricultural crops in Croatia will decrease by 3 to $8 \%$ due to climate change (The Ministry of Environment and Energy of the Republic of Croatia, 2017, p. 29). Because of the high value that agriculture creates in the overall economy of Croatia, the high number of employees in that sector and in jobs related to that sector, because of the need to ensure food security, etc., climate change is an important aspect of thinking about agricultural sustainability. Therefore, it is necessary that all who hold a stake in agriculture contribute to overcoming the negative impacts of climate change on farming (and vice versa) by exchanging information and integrating knowledge.

Agricultural advisory services are an important link in the process of communicating about the risks of climate change and the exchange of knowledge and learning between agricultural practice (producers) and scientists. Research from around the world shows that farmers who work with advisory services and related organizations are more successful in addressing the risks of climate change in their production (Mendelsohn and Dinar, 2003; Maddison, 2007; Preethi et al., 2013; Bryan et al., 2013; Di Falco 
and Veronesi, 2013; Shakra Juana et al., 2013; Di Falco, 2014). That is only true under the assumption that agricultural advisory services, that is, agricultural advisors, are aware of climate change and are well informed about the possible harmful effects of climate change on the sustainability of global and local agriculture. These are important predictors of activities that lead to the adaptation of farming to climate change.

There are no empirical insights into the opinions and attitudes of agricultural advisors or farmers on climate change in the domestic literature, although there are scientific and professional papers that analyze the possible negative and positive effects of climate change on domestic farming in general (Šimunić et al., 2007; Šimunić et al., 2014; Vučetić, 2014; South, 2016). It is worth mentioning recent research on general attitudes of citizens towards climate change, which shows that the population of Croatia is relatively well acquainted with some aspects of climate change (Landau et al., 2008; European Commission, 2014), and that most perceive them as a serious social problem, but on average a somewhat milder problem compared to citizens of the European Union (Ančić et al., 2016).

There are several recent studies in the foreign literature that consider the causes and consequences of climate change from the point of view of agricultural advisors. These studies indicate that attitudes of agricultural advisors on climate change are not unambiguous, but are instead shaped by acquired practical experience and knowledge, field of work or socio-demographic characteristics, and are under the influence of the local social environment in which they operate. In a survey in the Midwestern United States conducted on a representative sample of agricultural advisors in both public and private sectors, three-quarters of respondents expressed the opinion that climate change is happening, but have a divided opinion of the role of humans on the phenomenon (Mase, 2014). The author found that gender and affiliation of advisors to a private or public sector significantly determine their belief about the causes of climate change. Female respondents and advisors working in public advisory services were more likely to believe in anthropogenic causes of climate change. Although most advisors in this study agreed that farmers need to adapt to climate change, their views on how to adapt have varied significantly. Advisors who are fully or partially convinced that climate change is induced by human action are significantly more supportive of farming practices that have the potential to reduce vulnerability and improve adaptability to climate change.

Similarly, a survey of four US states that was part of the "Useful to Usable" project (U2U, 2016) found that 53\% of advisors believe that climate change is caused by human activity. Most of them (77\%) agree that the both-sided (farmer and advisor) use of a weather forecasting tool for making production decisions can result in better outcomes for agricultural economy and the environment.

Furthermore, the qualitative research of Church et al. (2017) on a sample of 36 agricultural advisors showed that they do not express much concern about climate change, although they largely accept that the occurrence of extreme weather conditions poses a risk to US agriculture. Finally, we mention an interesting study by Nilles et al. 
(2019) in which the authors linked the perceptions of agricultural advisors on climate change with five-year data on crop damage using structural equation modeling. The authors found that higher crop loss rates were associated with lower advisors' belief in the anthropogenic impacts on climate change.

In this article, we discuss how agricultural advisors in Croatia perceive climate change. The objectives of the study were to determine the extent to which agricultural advisors are aware of the anthropogenic impacts and wider consequences of climate change, to establish the level of their self-assessed knowledge of risks, and to find out about some of their experiences with the consequences of climate change and actions taken to mitigate it in domestic agriculture.

\section{Materials and methods}

The research was conducted using an online survey distributed among employees of the Croatian Agricultural and Forestry Advisory Service in May and June 2018. The online survey was filled out only by advisors working in the agriculture sector and rural development; the sample did not include forestry advisors. The survey was completely completed by 103 respondents (or 51.3\% of advisors not working in forestry), coming from all 21 Croatian counties.

The questions in the survey pertained to four thematic units: socio-demographic data, general views on climate change, knowledge about risks to global agriculture, and some aspects of the impact of climate change on domestic agriculture. Attitudes were measured using 16 statements summarizing three composite indicators: awareness of anthropogenic causes and consequences ( 8 items); mitigation responsibility ( 3 items); and indifference and defeatism towards climate change ( 5 items), to which respondents expressed their degree of (dis)agreement on a 5 point Likert-type scale (from 1 - "I completely disagree" to 5 - "I completely agree"). Most of these statements were taken from a study by Whitmarsh (2005) and adapted for this research.

Measurement scale reliability was assessed using Cronbach's reliability coefficient $(\alpha)$. All scales were found to show acceptable reliability $(\alpha \geq 0.7)$. Answers about climate change awareness and observed adverse impacts on domestic agriculture were obtained through a combination of open-ended and closed-ended questions.

Statistical analysis of the data included descriptive statistics (frequencies, proportions, means and standard deviations) and inferential analyses (Pearson's chi-squared tests of independence). Chi-squared tests $\left(\chi^{2}\right)$ were used to assess the statistical significance of differences in attitudes with respect to gender and age. Respondents were divided into two subgroups according to age: younger (up to 45 years) and older (46 years or more). Type I error rate was set to $5 \%(\alpha=0.05)$. Two-sided tests were used.

The survey data were analyzed using IBM SPSS Statistics for Windows, version 21.0 (IBM Corp., Armonk, N.Y., USA). 


\section{Results and discussion}

\section{Sample Structure}

Of 103 agricultural advisors who participated in the study, 58 were women and 45 were men (Table 1). The mean age of the participants was 46.5 years, ranging from 25 to 62. Respondents with 6 to 15 years of work experience in the advisory service (35.9\%) were the most common in the sample. When examined by field of work, advisors from plant production and plant protection dominated the sample $(61.2 \%)$.

Table 1. Sample description

\begin{tabular}{|l|l|l|l|}
\hline \multicolumn{2}{|c|}{ Features } & f & \% \\
\hline \multirow{2}{*}{ Gender } & Men & 45 & 43.7 \\
\cline { 2 - 4 } & Women & 58 & 56.3 \\
\hline \multirow{3}{*}{ Age (year) } & $25-35$ & 19 & 18.4 \\
\cline { 2 - 4 } & $36-45$ & 26 & 25.3 \\
\cline { 2 - 4 } & $46>$ & 58 & 56.3 \\
\hline \multirow{3}{*}{ Level of education } & College of higher education & 98 & 95.1 \\
\cline { 2 - 4 } & PhD & 5 & 4.9 \\
\hline \multirow{3}{*}{$\begin{array}{l}\text { Work experience in the Advisory Service } \\
\text { year) }\end{array}$} & $1-5$ & 31 & 30.1 \\
\cline { 2 - 4 } & $6-15$ & 37 & 35.9 \\
\cline { 2 - 4 } & $16>$ & 35 & 34.0 \\
\hline \multirow{5}{*}{ Field of work } & Plant production and plant protection & 63 & 61.2 \\
\cline { 2 - 4 } & Livestock production & 26 & 25.2 \\
\cline { 2 - 4 } & Rural Development, Economics, Fisheries & 10 & 9.7 \\
\cline { 2 - 4 } & Combination & 4 & 3.9 \\
\hline
\end{tabular}

\section{Perception of Climate Change}

Knowledge and conviction of each individual, social group and community that climate change is happening, as well as knowledge and understanding of anthropogenic causes of climate change and possible harmful effects on society and the environment are requirements for effective action in reducing climate change risk. Numerous empirical studies have shown that the formation of subjective attitudes about the causes and consequences of climate change is influenced by a number of factors such as: experience of a problem related to climate change as opposed to anticipated problems, confidence in the credibility of scientific information, level of knowledge, conflict between economic and environmental priorities, ecological worldview and values, cultural characteristics, public opinion in the local environment, etc. (Fielding et al., 2014). Depending on these factors, different notions about the problem of climate change establish themselves: conviction, skepticism or denial.

Awareness of the existence of climate change and familiarity of agricultural advisors with it are key to achieving the full reach of agriculture resistant to climate change, but also its contribution to change mitigation. We conceptualized the problem of climate change in 16 statements to gain insight into the general attitudes of agricultural 
advisors about the phenomenon. Distributions of degrees of agreement with individual statements and mean values (M) are presented in the Table 2.

Among the eight statements that make up the composite indicator "awareness of anthropogenic causes and consequences of climate change" (Table 2), respondents agreed the most with statement number 4, i.e., that climate change can be disastrous for human survival $\left(\mathrm{M}_{4}=4.30\right)$. There was also a very high degree of agreement with the statements expressing the views that climate change seriously endangers the world's farming $\left(\mathrm{M}_{8}=4.22\right)$ and biodiversity $\left(\mathrm{M}_{6}=4.00\right)$. Although there was on average a slightly lower degree of agreement about the causes of climate change, most respondents still see it as a consequence of the modern society's way of life $(61.1 \%)$ and the large contribution of industry $(58.3 \%)$ and agriculture $(52.4 \%)$ to global warming. Similar findings about beliefs of agricultural advisors on the anthropogenic causes of climate change have been obtained in some foreign studies (Mase, 2014; U2U, 2016). It is also interesting that $40.8 \%$ of surveyed advisors are "indecisive" ("neither agree nor disagree") in detecting agriculture as the cause of climate change, while $6.8 \%$ of them believe that agriculture does not contribute to the creation of climate change.

The belief of the majority of respondents in the anthropogenic impact on climate change is supported by the high degree of their agreement with the three statements describing the indicator "responsibility in climate change mitigation." Among the individual statements, respondents agree the most with the statement that governments and policies need to make more concrete actions about climate change $\left(\mathrm{M}_{11}=4.25\right)$. Also, $84.4 \%$ of respondents believe that each of us has a moral responsibility to alleviate this global problem $\left(\mathrm{M}_{9}=4.21\right)$, and about two thirds $(62.1 \%)$ agree that changes in human activities and consumption are key to mitigate them $\left(\mathrm{M}_{10}=3.72\right)$.

Table 2. The general attitude on climate change

\begin{tabular}{|c|c|c|c|c|c|}
\hline \multirow[t]{2}{*}{ Indicators with individual statements } & \multicolumn{3}{|c|}{$\begin{array}{l}\text { Level of agreement* } \\
(\%)\end{array}$} & \multirow{2}{*}{$\mathbf{M}_{\mathrm{i}}$} & \multirow[t]{2}{*}{ SD } \\
\hline & 1,2 & 3 & 4,5 & & \\
\hline \multicolumn{6}{|l|}{ Awareness of anthropogenic causes and consequences } \\
\hline 1. Climate change is a result of modern society lifestyle. & 10.7 & 28.2 & 61.1 & 3.66 & 0.996 \\
\hline $\begin{array}{l}\text { 2. Industry contributes most to global warming and } \\
\text { climate change. }\end{array}$ & 9.7 & 32.0 & 58.3 & 3.63 & 0.918 \\
\hline $\begin{array}{l}\text { 3. Agriculture has a large share in the creation of } \\
\text { climate change. }\end{array}$ & 6.8 & 40.8 & 52.4 & 3.53 & 0.777 \\
\hline $\begin{array}{l}\text { 4. Climate change can be catastrophic for the survival } \\
\text { of mankind. }\end{array}$ & 3.8 & 6.8 & 89.4 & 4.30 & 0.838 \\
\hline $\begin{array}{l}\text { 5. The natural equilibrium (eco-system stability) has } \\
\text { never been more vulnerable than today. }\end{array}$ & 8.7 & 27.2 & 64.1 & 3.75 & 0.936 \\
\hline 6. Climate change seriously endangers biodiversity. & 3.8 & 15.5 & 80.7 & 4.00 & 0.816 \\
\hline $\begin{array}{l}\text { 7. Floods and droughts are exclusively consequences } \\
\text { of climate change. }\end{array}$ & 14.5 & 28.2 & 57.3 & 3.52 & 0.927 \\
\hline $\begin{array}{l}\text { 8. Climate change seriously threatens farming in the } \\
\text { world. }\end{array}$ & 3.9 & 9.7 & 86.4 & 4.22 & 0.917 \\
\hline
\end{tabular}




\begin{tabular}{|c|c|c|c|c|c|}
\hline \multirow[t]{2}{*}{ Indicators with individual statements } & \multicolumn{3}{|c|}{$\begin{array}{l}\text { Level of agreement* } \\
(\%)\end{array}$} & \multirow[t]{2}{*}{$\mathbf{M}_{\mathbf{i}}$} & \multirow[t]{2}{*}{ SD } \\
\hline & 1,2 & 3 & 4,5 & & \\
\hline \multicolumn{6}{|l|}{ Responsibility in mitigation of climate change } \\
\hline $\begin{array}{l}\text { 9. As individuals we are all morally responsible for } \\
\text { climate change mitigation. }\end{array}$ & 3.9 & 11.7 & 84.4 & 4.21 & 0.836 \\
\hline $\begin{array}{l}\text { 10. Changes in human activities / consumption are key } \\
\text { for climate change mitigation. }\end{array}$ & 5.9 & 32.0 & 62.1 & 3.72 & 0.833 \\
\hline $\begin{array}{l}\text { 11. Governments / politics have to deal more concretely } \\
\text { with climate change issues. }\end{array}$ & 2.9 & 6.8 & 90.3 & 4.25 & 0.825 \\
\hline \multicolumn{6}{|l|}{ Indifference and defeatism towards climate change } \\
\hline $\begin{array}{l}\text { 12. There are more important problems (issues) than } \\
\text { climate change. }\end{array}$ & 45.7 & 37.9 & 16.4 & 2.63 & 0.950 \\
\hline $\begin{array}{l}\text { 13. Nature (the natural environment) can fight climate } \\
\text { change by itself. }\end{array}$ & 67.0 & 26.2 & 6.8 & 2.38 & 0.933 \\
\hline $\begin{array}{l}\text { 14. The scientists exaggerate with their forecasts of the } \\
\text { climate change consequences for the Earth. }\end{array}$ & 68.0 & 20.4 & 11.6 & 2.15 & 1.115 \\
\hline $\begin{array}{l}\text { 15. Media often exacerbates the consequences of } \\
\text { climate change. }\end{array}$ & 34.0 & 38.8 & 27.2 & 2.91 & 0.951 \\
\hline 16. It's too late to fight climate change. & 58.2 & 29.1 & 12.7 & 2.40 & 0.953 \\
\hline
\end{tabular}

${ }^{*} 1$ = I totally disagree; $2=\mathrm{I}$ disagree; $3=\mathrm{I}$ do not agree nor disagree; $4=\mathrm{I}$ agree; $5=\mathrm{I}$ completely agree

Some previous research has shown that respondents have diverse attitudes toward some aspects of climate change, even within the same sample (Whitmarsh, 2005; Poortinga et al., 2011). We checked for the presence of possible inconsistencies in the attitudes of our respondents with negatively scored statements that collectively make up the indicator "indifference and defeatism towards climate change." Based on the mean values and percentages denoting disagreement on most of these statements, it can be concluded that respondents have a relatively consistent general view about the causes and consequences of climate change, on average. Respondents expressed the least disagreement (34.0\%) with the statement about the media's exaggerations of the consequences of climate change $\left(\mathrm{M}_{15}=2.91\right)$. Although some advisors $(27.2 \%)$ agree with this statement, we consider it an expression of their distrust in the credibility of information provided by some public media.

Contingency analysis $\left(\chi^{2}\right)$ found that there was no statistically significant difference in the level of agreement with most individual statements with respect to gender and age of the respondents. The only significant gender differences were found in two statements: "Nature (natural environment) can fight climate change on its own" $\left(\chi^{2}=\right.$ $10.120, \mathrm{P}=0.006)$ and "Media often exaggerate the consequences of climate change" $\left(\chi^{2}=7.817, \mathrm{P}=0.033\right)$. Disagreements ("I completely disagree" and "I disagree") with these statements are significantly more often expressed by female advisors $(77.6 \%)$ compared to their male colleagues $(53.3 \%)$, indicating their greater conviction in the need for social intervention in mitigating the effects of climate change on the natural environment. Also, it was shown that younger respondents expressed a higher degree 
of agreement statistically significantly more often compared to older advisors on three statements: "Industry contributes the most to global warming and climate change" $\left(\chi^{2}=8.507, \mathrm{P}=0.014\right)$, "Natural balance (ecosystem stability) has never been more endangered than it is today" $\left(\chi^{2}=8.194, \mathrm{P}=0.010\right)$, and "Climate change is seriously threatening biodiversity" $\left(\chi^{2}=8.858, \mathrm{P}=0.012\right)$. These data indicate that younger advisors are more concerned about human disturbance of natural rhythms and have a stronger sense of ethical concern for maintaining biodiversity.

Based on mean values of the three composite attitude indicators (Table 3), it can be concluded that the surveyed advisors agree the most on average with statements about political and civic responsibility in climate change mitigation $\left(\mathrm{M}_{\mathrm{KI}}=4.06\right)$.

Table 3. Average values of climate change attitudes composite indicators

\begin{tabular}{|l|l|l|l|}
\hline Indicator & $\mathbf{M}_{\mathrm{KI}}$ & SD & $\begin{array}{l}\text { C r o n b a c h } \\
\text { alfa }(\boldsymbol{\alpha})\end{array}$ \\
\hline Awareness of anthropogenic causes and consequences $\left(\mathrm{M}_{\mathrm{KJS}}\right)$ & 3.828 & 1.674 & 0.753 \\
\hline The responsibility in the mitigation of climate change $\left(\mathrm{M}_{\mathrm{KJ} \mathbf{}}\right)$ & 4.061 & 1.080 & 0.701 \\
\hline $\begin{array}{l}\text { Indifference and defeatism } \\
\left(\mathrm{M}_{\mathrm{KId}}\right)\end{array}$ & 2.434 & 1.665 & 0.710 \\
\hline
\end{tabular}

Furthermore, respondents on average display a satisfactory level of awareness of the causes and possible wider consequences of climate change on society and the environment $\left(\mathrm{M}_{\mathrm{KIs}}=3.83\right)$. This is also indicated by the low degree of agreement on the composite indicator "indifference and defeatism" $\left(\mathrm{M}_{\mathrm{KId}}=2.43\right)$, although it should be noted that a small number of advisors nevertheless has an ambivalent attitude towards climate change.

\section{Self-Assessed Knowledge and Trust in Information Sources}

Giving the public access to credible information about the causes and risks of climate change increases the likelihood of making informed responses and proactive action with the goal to adapt to and mitigate negative effects on the environment and climate. When it comes to agriculture, the scientific, professional and political public agrees that climate change can have very detrimental effects on future farming, thus threatening global / local food security. Consequently, it is very important that agricultural advisors are well informed about the possible risks of climate change in farming, as insufficient information often leads to an unrealistic assessment of the degree of danger. In this study, we examined only advisors' subjective assessments of their general knowledge about these risks, and determined which sources they consider the most credible.

From the answers we can see that $72.8 \%$ of respondents think that they are well informed about the possible consequences of climate change in agriculture, $20.4 \%$ assess their knowledge as moderate, while $6.5 \%$ state that they either are not or do not know if they are sufficiently aware of these risks. Participants who consider themselves well informed most often see the risks of climate change on global agriculture in: reduced yields and product quality, disruptions in production cycles, emergence of new pests and diseases, 
loss of arable land, loss of soil fertility, impaired domestic animal health, higher prices of agricultural products, reduction in general crop and livestock production globally, food shortages, pollution of drinking water, etc. However, in order to obtain an accurate insight into the real level of agricultural advisors' knowledge about these risks, an objective knowledge test should be applied in addition to a subjective assessment.

When asked whose information they trust the most, more than three quarters of the surveyed advisors $(81.6 \%)$ decided to answer "scientists." The rest believe the most in the information they receive from agrometeorological experts, from their more experienced colleagues they work with $(6.8 \%)$, or from farmers $(5.8 \%)$. The remaining respondents answered "I don't know" or that they believe "their own observations" the most. Interestingly, none of the respondents chose the answer "government organizations," although in answers concerning their attitudes (Table 2, statement 11) they emphasize the necessity of greater engagement and action from political elites in the fight against climate change.

\section{Some Experiences with the Consequences of Climate Change in Domestic Agriculture}

It is well known that Croatia, due to its climatic and geographical characteristics, is one of the countries with greater vulnerability to climate change, especially its primary sector (agriculture, forestry and fisheries). The experiences of local agricultural advisors (and farmers) are extremely important for determining appropriate agro-technical measures for adapting farming to climate change, as their consequences are not spatially uniform. Through several questions, we tried to determine whether agricultural advisors see climate change as problematic for domestic agriculture, what harmful consequences of climate change do farmers or users of their services face, and whether they carry out professional training on these issues.

Table 4 shows the proportions of the answers to the question "Do you think that climate change seriously endangers domestic farming?" It is evident from the table that there is a relatively high proportion (61.2\%) of agricultural advisors who see climate change as a threat to the stability of domestic production at the level of the entire sample. The analysis revealed a statistically significant difference in the respondents' responses by gender $(\mathrm{P}=0.014)$. Differences in the proportion of younger and older advisors who consider climate change a serious threat to domestic farming were not significant.

Table 4. Do you think climate change seriously endangers domestic farming?

\begin{tabular}{|c|c|c|c|c|c|}
\hline \multirow[t]{2}{*}{ Answers } & Men & Women & $\begin{array}{l}\text { Younger } \\
(25-45) \\
\end{array}$ & $\begin{array}{l}\text { Elder } \\
(46>)\end{array}$ & All respondents \\
\hline & $\%$ & $\%$ & $\%$ & $\%$ & $\%$ \\
\hline Yes, it seriously endangers & \begin{tabular}{|l|l|}
71.1 \\
\end{tabular} & 53.5 & 68.9 & 55.2 & 61.2 \\
\hline $\begin{array}{l}\text { Neither yes nor no, } \\
\text { (moderately) }\end{array}$ & 17.8 & 43.1 & 22.4 & 37.9 & 32.0 \\
\hline It does not endanger & 11.1 & 3.4 & 6.7 & 6.9 & 6.8 \\
\hline Sig. & \multicolumn{2}{|c|}{$\chi^{2}=8.555 ; \mathrm{P}=0.014$} & \multicolumn{2}{|c|}{$\chi^{2}=2.222 ; \mathrm{P}=0.330$} & 100.0 \\
\hline
\end{tabular}


Extreme weather events which, among other things, cause direct damage to agriculture have been evident in Croatia in recent years. The next question in the survey pertained to the advisors' knowledge about the frequency and harmful consequences of some phenomena of climate change encountered by farmers in their area. As can be seen from Table 5, drought was among the most frequently mentioned weather disasters, which according to the respondents $(63.1 \%)$ often (or every year) occurred in their area, causing damage to crops. The most commonly cited consequences of bad weather were reduced yields in production, followed by the emergence of new plant diseases and soil erosion.

Table 5. The frequency of consequences occurrence of climate change by the user

\begin{tabular}{|l|l|l|l|}
\hline \multicolumn{1}{|c|}{ Consequences } & Often, every year & Rarely, once in five years & Never \\
\hline Drought & 63.1 & 35.9 & 1.0 \\
\hline Flood & 21.4 & 68.0 & 10.6 \\
\hline Soil erosion (agricultural land) & 35.0 & 49.5 & 15.5 \\
\hline $\begin{array}{l}\text { The appearance of new plant diseases / } \\
\text { pests }\end{array}$ & 43.7 & 46.6 & 9.7 \\
\hline Yeld reduction & 61.2 & 37.8 & 1.0 \\
\hline
\end{tabular}

In adapting agriculture to climate change, agricultural advisory services are key links between farmers and sources of new information and knowledge about adaptive production options and their reporting at the local farm level (Simpson and Burpee, 2014). The task of the advisor is, based on relevant agroclimatic data and research, to help farmers to develop knowledge and practical skills in order to transform existing and introduce new production practices more successfully; practices that are more resistant to climate change and less harmful to the environment.

The results of our research show that the vast majority of surveyed advisors $(84.5 \%)$ hold professional lectures or workshops on topics related to the adaptation of agriculture to climate change annually (Table 6). These professional lectures are mainly part of the educational packages intended for the beneficiaries of Measure 10 (Agriculture, Environment and Climate Change) and Measure 11 (Organic Farming) of the Rural Development Program. Lectures and workshops cover a wide range of topics, such as: "Adaptation of agricultural crops to climate change," "The impact of agriculture on climate change and climate change mitigation," "Soil erosion caused by climate change," "Pest spread caused by climate change," "Sustainable management of soil, water, fertilizers and pesticides," "Agriculture and plant protection from fire under the influence of extreme weather events," etc. Also, some respondents state that they present comparative data on precipitation and temperatures at the local level to farmers as part of their lectures on farming. That way the farmers can take appropriate action on the farm in advance in case of forecasted weather disasters. 
Table 6. The organization of professional lectures/workshops on climate change

\begin{tabular}{|l|l|l|}
\hline \multicolumn{1}{|c|}{$\begin{array}{c}\text { Number of lectures } / \\
\text { workshops }\end{array}$} & \multicolumn{1}{c|}{$\mathbf{f}$} & \\
\hline $1-10$ per year & 47 & 55.3 \\
\hline $11-20$ per year & 18 & 21.2 \\
\hline $20>$ per year & 20 & 23.5 \\
\hline Total & 85 & 100.0 \\
\hline
\end{tabular}

Despite the fact that farmers in Croatia are facing rising risks of climate change (as illustrated in Table 5), according to agricultural advisors they relatively rarely seek advice on how to better deal with these problems. Namely, when asked how often farmers ask them for advice on adapting their production to climate change, more than two thirds of respondents $(68.9 \%)$ stated that they do so very rarely or only occasionally, while only $31.1 \%$ answered that farmers often or very often they seek this advice. Farmers seeking advice are adapting to climate change depending on production, by introducing irrigation of their crops, hail protection nets, application of agrotechnical measures to prevent soil erosion, early sowing, foliar fertilization, green fertilization, new more resistant crops, new methods of disease and pest control, reduced tillage, etc. Also, some advisors state that they advise farmers to insure crops against the possible negative effects of climate change.

Planning adaptation in agriculture aligned with climate change largely depends on the education of farmers and their ability to articulate appropriate solutions in their production. The survey showed that agricultural advisors are very critical of Croatian farmers' education on climate change; as many as $92.4 \%$ of respondents believe that farmers do not have appropriate knowledge, which can significantly slow down the process of adapting domestic agriculture to climate change.

\section{Conclusions}

Knowledge and awareness of the relationship between causes and consequences of climate change is a prerequisite for undertaking systematic and coordinated societal activities on a global and local level, for mitigating their negative effects on people and the economy, as well as for reducing pollution and environmental degradation. Because climate change is considered an important risk in farming, many authors emphasize the role of agricultural and related services in propagating climate information and training farmers to successfully implement innovative agricultural technologies and practices resistant to climate variation. This assumes that agricultural advisors are well informed about the nature and extent of the risks associated with climate change in local agriculture.

The basic findings of this research indicate that most agricultural advisors in Croatia are aware of the anthropogenic impact on climate change and its wider consequences for human communities and ecosystems. This is confirmed by the relatively high degree of their agreement with statements primarily about political $(\mathrm{M} 11=4.25)$, but also about civic responsibility $(\mathrm{M} 9=4.21)$ in climate change mitigation. Most advisors consider 
themselves well informed about the possible risks and harmful consequences that climate change brings to agriculture, and consider the information coming from scientists to be the most credible. The results of the research showed that about two thirds of the surveyed advisors perceive climate change as dangerous for the stability of domestic farming, and as many as $92.4 \%$ of them believe that Croatian farmers do not have the necessary knowledge to successfully deal with climate change risks in their own production.

Ultimately, climate change is certainly a great challenge not only for Croatian agriculture but also for the wider economy and society. Consequently, it is necessary to conduct systematic, comprehensive, and interdisciplinary research in order to obtain information on climate change based on science, but also research that examines the views of the public. This will lead to a better understanding and harmonization of approaches in planning desirable social interventions. It is necessary to develop human capital - knowledge, skills and abilities of farmers which would allow them to cope with the consequences of climate change, but it is also necessary to act on mitigating the harmful effects of agriculture on the climate and the environment.

\section{Conflict of interests}

The authors declare no conflict of interest.

\section{References}

1. Ančić, B., Puđak, J., \& Domazet, M. (2016). Do we see climate change in Croatia? Research of attitudes on some of the aspects of climate change in Croatian society. Hrvatski meteorološki časopis, 51(51), 27-45. [in Croatian: Vidimo li klimatske promjene u Hrvatskoj? Istraživanje stavova o nekim od aspekata klimatskih promjena u hrvatskom društvu]

2. Bryan, E., Ringler, C., Okoba, B., Roncoli, C., Silvestri, S. \& Herrero, M. (2013). Adapting agriculture to climate change in Kenya: household strategies and determinants. Journal of Environmental Management, 114, 26-35. https://doi. org/10.1016/j.jenvman.2012.10.036

3. Church, S.P., Dunn, M., Babin, N., Mase, A.S., Haigh, T., \& Prokopy, L.S. (2017). Do advisors perceive climate change as an agricultural risk? An in-depth examination of Midwestern U.S. Ag advisors' views on drought, climate change, and risk management. Agriculture and Human Values, Springer; The Agriculture, Food, \& Human Values Society (AFHVS), 35(2), 349-365. https://doi: 10.1007/ s10460-017-9827-3

4. Derpsch, R. (2008). No-tillage and conservation agriculture: a progress report. In: Goddard, T., Zobisch, M.A., Gan, Y.T., Ellis W, Watson, A., Sombatpanit, S., eds. No-till Farming Systems. Special Publication No. 3. Bangkok, Thailand: World Association of Soil and Water Conservation, 7-39. 
5. Di Falco, S. (2014). Adaptation to climate change in Sub-Saharan agriculture: assessing the evidence and rethinking the drivers. European Review of Agricultural Economics, 41(3), 405 -430. https://doi: 10.1093/erae/jbu014

6. Di Falco, S., \& Veronesi, M. (2013). How African agriculture can adapt to climate change? A counterfactual analysis from Ethiopia. Land Economics, 89(4), 743 -766. https://doi.org/10.3368/le.89.4.7436

7. Donnelly, D., Mercer, R., Dickson, J., \& Wu, E. (2009). Australia's Farming Future Final Market Research Report: Understanding Behaviours, Attitudes and Preferences Relating to Climate Change. [Online] Sydney, NSW, Australia: Instinct and Reason. Retrieved from http://www.agriculture.gov.au/ SiteCollectionDocuments/climatechange/australias-farming-future/aus-farmingfuture-mrr.pdf (18 March 2019).

8. European Commission (2014). Climate change. Special Eurobarometer 409. [Online]: Directorate-General for Climate Action (DG CLIMA) i DirectorateGeneral for Communication. やRetrieved from http:/ec.europa.eu/commfrontoffice/ publicopinion/archives/ebs/ebs_409_en.pdf (February 21, 2019).

9. Fielding, K.S., Hornsey, M.J., \& Swim, J.K. (2014). Developing a social psychology of climate change. Eur. J. Soc. Psychol., 44(5), 413-420. https://doi.org/10.1002/ ejsp. 2058

10. Howel, P.D., Mildenberger, M., Marlon, J.R., \& Leiserowitz, A. (2015). Geographic variation in opinions on climate change at state and local scales in the USA. Nature Climate Change, 5, 596-603.

11. Juhola, S., Klein, N., Käyhkö, J., \& Schmid Nesetc, T.S. (2017). Climate change transformations in Nordic agriculture? Journal of Rural Studies, 51, 28-36. https:// doi.org/10.1016/j.jrurstud.2017.01.013

12. Landau, S., Legro, S., \& Vlašić, S. (2008). Good climate for change. Climate change and its consequences on society and the economy in Croatia, Climate change and their consequences on society and the economy in Croatia. [Online]: や Program Ujedinjenih naroda za razvoj (UNDP) u Hrvatskoj, http://klima.hr/ razno/priopcenja/NHDR_HR.pdf [Accessed 20 February 2019].[in Croatian: Dobra klima za promjene. Klimatske promjene i njihove posljedice na društvo i gospodarstvo u Hrvatskoj, Klimatske promjene i njihove posljedice na društvo i gospodarstvo u Hrvatskoj]

13. Maddison, D. (2007). The perception of and adaptation to climate change in Africa. Policy Research Working Paper 4308. The World Bank, Development Research Group, Sustainable Rural and Urban Development Team. Retrieved from https:// openknowledge.worldbank.org/handle/10986/7507

14. Mase, A.S. (2014). Climate change risks, information, and adaptation: Perspectives of midwestern U.S. farmers and advisors. [Online]: [West Lafayette, Indiana: Purdue University. Retrieved from https://search.proquest.com/docview/1648677604?acc ountid=168605 [Accessed 21 February 2019]. 
15. Mendelsohn, R., \& Dinar, A. (2003). Climate, water, and agriculture. Land Economics, 79(3), 328-341.

16. The Ministry of Environment and Energy of the Republic of Croatia (2017). Subactivity 2.3.1.: Report on assessed impacts and vulnerabilities to climate change by individual sectors. [Online] Zagreb: Ministarstvo zaštite okoliša i energetike RH. [in Croatian: Podaktivnost 2.3.1.: Izvještaj o procijenjenim utjecajima i ranjivosti na klimatske promjene po pojedinim sektorima] Retrieved from http://prilagodbaklimi.hr/wp-content/uploads/2017/11/Procjena-ranjivosti-na-klimatske-promjenefinal.pdf [Accessed 20 March 2019].

17. Preethi Chandrashekar, S.V., Sunitha. A.B., \& Manjula, C.N. (2013). A Comparative Study on Perception of Agro - met Advisory Service (AAS) towards Climate Change. Journal of Agricultural Science, 5(4), 357-360.

18. Simpson, B.M., \& Burpee, C.G. (2014). Adaptation under the New Normal of Climate Change: The Future of Agricultural Extension and Advisory Services. Online] MEAS Discussion Paper Series on Good Practices and Best Fit Approaches in Extension and Advisory Service Provision. Retreived from https://www.agrilinks. org/sites/default/files/resource/files/MEAS\%20Discussion $\% 20$ Paper $\% 203 \% 20$ -\%20Climate\%20Change\%20and\%20EAS\%20-\%202014_01_31.pdf (April 4, 2019).

19. Šimunić, I., Husnjak, S., \& Tomić, F. (2007). Influence of drought on reduction of yields of agricultural crops. Agronomski glasnik, 69 (5), 343-354. [in Croatian: Utjecaj suše na smanjenje prinosa poljoprivrednih kultura]

20. Šimunić, I., Spalević, V., Vukelić-Shutoska, M., Šoštarić, J., \& Marković, M. (2014). Impact of water shortage in the soil on crop yields. Hrvatske vode, 22 (89), 203-212. [in Croatian: Utjecaj vode u tlu na prinose poljoprivrednih kultura]

21. Thierfelder, C., \& Wall, P.C. (2009). Effects of conservation agriculture techniques on infiltration and soil water content in Zambia and Zimbabwe. Soil and Tillage Research, 105(2), 217-227. https://doi.org/10.1016/j.still.2009.07.007

22. Vučetić, V. (2014). Utjecaj klimatskih promjena na poljoprivrednu proizvodnju. U: Vučetić, V., Agrometeorologija u službi korisnika: „Zaštita okoliša i poljoprivreda“" Dubrovnik, Hrvatska, 22.03.2014., Hrvatsko agrometeorološko društvo, 1-2.

23. Whitmarsh, L.E. (2005). A study of public understanding of and response to climate change in the South of England. [Online] Bath, UK: University of Bath, Retrieved from https://sp.ukdataservice.ac.uk/doc/5345/mrdoc/pdf/5345thesis.pdf (April 4, 2019). 